\title{
Satisfaction of octogenarians with Primary Health Care services
}

\author{
Luan Augusto Alves Garcial $\mathbb{D}$ \\ Giovanna Gaudenci Nardelli' ${ }^{1}$ \\ Ana Flávia Machado de Oliveira² \\ Luiza Elena Casaburi ${ }^{3}$ (D) \\ Fernanda Carolina Camargo $4 \mathbb{D}$ \\ Álvaro da Silva Santos ${ }^{5} \mathbb{D}$
}

\section{Abstract}

Objective: To evaluate the satisfaction of octogenarians with Primary Health Care services. Method: a descriptive study, with a quantitative approach, was carried out with 30 older users of the Family Health Strategy, selected by a non-probabilistic sample. Data were collected at home, using the following questionnaires: the mini-mental state exam, a questionnaire on sociodemographic factors, health conditions and access to services, and a questionnaire on satisfaction with Primary Health Care. Data were analyzed using descriptive statistics. Results: The satisfaction analysis showed that the elderly octogenarians are satisfied in terms of care $(\hat{X}=6,0 ; \pm 1,5)$ and the interest that community agents demonstrate in them $(\dot{X}=5,9 ; \pm 1,6)$ and the availability of nurses for their treatment $(\dot{X}=5,9 ; \pm 1,1)$. Aspects related to the waiting time for nurses $(\dot{X}=4,6 ; \pm 1,6)$ and doctors $(\dot{X}=4,9 ; \pm 1,6)$, facilities for the disabled $(\dot{X}=4,6 ; \pm 1,4)$ and the perception that the unit is close to a perfect health unit $(\dot{X}=4,6 ; \pm 1,8)$. Conclusion: The services were positively evaluated, reflecting the importance of considering the perspective of octogenarian users in the planning of healthcare actions, since the evaluation of the quality of these services can lead to changes and guide actions in a way that is coherent with the lives of users, increasing their effectiveness, especially regarding actions aimed at the octogenarian population.

1 Universidade Federal do Triângulo Mineiro, Instituto de Ciências da Saúde, Programa de Pós-graduação em Atenção à Saúde. Uberaba, Minas Gerais, Brasil.

2 Universidade Federal do Triângulo Mineiro, Instituto de Ciências da Saúde, Curso de Graduação em Enfermagem. Uberaba, Minas Gerais, Brasil.

3 Universidade de Uberaba, Curso de Graduação em Enfermagem. Uberaba, Minas Gerais, Brasil.

4 Universidade Federal do Triângulo Mineiro, Hospital de Clínicas, Setor de Vigilância em Saúde e Segurança do Paciente. Uberaba, Minas Gerais, Brasil.

5 Universidade Federal do Triângulo Mineiro, Instituto de Ciências da Saúde, Programa de Pós-graduação em Atenção à Saúde, Departamento de Enfermagem em Educação e Saúde Comunitária. Uberaba, Minas Gerais, Brasil.
The authors declare there are no conflicts of interest in relation to the present study.

Funding: Coordination for Higher Education Staff Development (Capes, Coordenação de Aperfeiçoamento de Pessoal de Nível Superior) - Number of process: 001.
Keywords: Aged 80 and over. Patient Satisfaction. Family Health Strategy. Primary Health Care. 


\section{INTRODUCTION}

Population aging is a worldwide phenomenon ${ }^{1}$. Data from the 2010 census show that this process is occurring in Brazil at a highly accelerated rate ${ }^{2}$, with octogenarians (the age group equal to or over 80 years) the fastest growing group, representing about $14.4 \%$ of the total number of older adults, or $1.5 \%$ of the entire Brazilian population ${ }^{1}$.

An important issue related to this scenario is that the increase in longevity is accompanied by higher levels of diseases that can cause disability and dependence, impacting the functional capacity of these older adults, in both physical and mental aspects, as well as their independence in carrying out basic and instrumental activities of daily living. Such impairments may result in complications such as physical disability, frailty, institutionalization and early death ${ }^{3}$.

This scenario presents challenges for care in terms of safety and quality, as octogenarians can be affected by multiple diseases and make intense use of health services. Thus, the provision of health care to this population must occur at the right time, in the appropriate place, and is crucial for the maintenance of the health conditions of these people ${ }^{4}$.

In this context, Primary Health Care (PHC) services should be the preferential contact of users with health systems ${ }^{5}$, especially for octogenarians, due to the greater proximity of access and greater bond created with the professionals from these services ${ }^{6}$. Above all, regular and effective monitoring of PHC services can avoid complications among this population, so that they can live, even with health problems, with quality of life $\mathrm{f}^{5,7-9}$.

In this perspective, the evaluation of health services is an essential initiative to diagnose and institute actions that bring the population's expectations closer to the reorganization of the care model. As a result, it must be able to support decision making to promote the effectiveness of programs and efficient use of resources ${ }^{10}$.

Thematic health assessment has received increasing interest from managers and researchers. Health assessment comprises a participatory process in which the user is a provider of important information, essential for completing and balancing the quality of services.

Most service evaluation studies consider only the perception of care offered to users, with those that address the organization of actions in a more comprehensive manner, related to the work performed by health teams, still incipient ${ }^{6,10,11}$. Thus, there are several instruments ${ }^{11}$ used to measure the satisfaction of PHC services, such as the Primary Care Assessment Tool (PCATool), the external evaluation instrument of the Primary Care Access and Quality Improvement Program and the Satisfaction with Primary Health Care questionnaire used in this study.

In this sense, due to population aging and the increasing proportion of octogenarians and their specific demands, it is crucial to include this age group in the processes of evaluating satisfaction with the health care provided. In addition, the evaluation of PHC services by these users is also relevant because it is the point of the Health Care Network (HCN) closest to this population ${ }^{6}$.

Thus, the challenge emerges when conceiving the evaluation of services, through the participation of long-lived older adults. Despite the limitations that these older adults may have, especially those related to the aging process, there is an urgent need to carry out research that includes the perception of this population regarding the standard of health services. Including the perspective of long-lived older users in the evaluation of PHC services represents a quality indicator, allowing the tailoring of actions that address the health needs of this age group ${ }^{7.11}$. Therefore, the following question emerges: How do octogenarians assess their satisfaction with primary care?

The present study aimed to analyze the satisfaction of octogenarians with Primary Health Care services.

\section{METHOD}

This is a descriptive study, with a cross-sectional design, of the household survey type. This research is part of a larger project entitled "Knowledge of HIV/AIDS and satisfaction with the health service of older users of the Family Health Strategy", carried 
out in the urban area of a city in the state of Minas Gerais, Brazil, in 2017.

The place of study is a hub municipality in the Health Macro-Region of the Triângulo Sul, in the state of Minas Gerais, Brazil, with an estimated population of 333,783 inhabitants in 2020, presenting specificity in relation to the proportion of octogenarians, considering that the state of Minas Gerais has a prevalence of $14.3 \%$ and the municipality of this study a proportion of $14.2^{\%} \%^{12}$.

The selection of participants for the present study came from the database of the larger project, composed of 238 older adults ${ }^{13}$. From this database, an intentional, non-probabilistic sample was selected, by inviting older adults who fit the following inclusion criteria: octogenarians (80 years of age or older) who had been registered with the PHC service of the Family Health Strategy type (or ESF), for at least six months, and who had had at least one appointment at the registered health unit and did not exhibit cognitive decline. Thirty older adults who met the inclusion criteria were identified.

Subsequently, visits were made to the homes of these octogenarians, with direct interviews being carried out by a previously trained team, composed of four students from the research group, between January and April 2017. The visits with the interviews lasted an average of 60 minutes and took place between May and December 2017, in the presence of family members and/or caregivers if the older adult so desired, helping the participants if they had any questions.

Initially, the older adults were assessed for cognitive decline by means of the Mini Mental State Examination (MMSE), which performs screening for the presence of cognitive decline. The following were considered cutoff points, based on the education of the older adults, namely: 13 points for illiterates, 18 points for from schooling from 1 to 11 years and 26 points for schooling for over 11 years ${ }^{14}$.

A questionnaire prepared by the researchers (tested in a pilot study) was used for the sociodemographic variables (age, sex, marital status, self-declared race/skin color, religion, education, retirement, professional occupation, individual income, family income, number of children, number of people living in the participant's home and household arrangements), health conditions (alcohol and tobacco consumption, physical activity, type of physical activity and self-reported morbidities) and access to services (health services that the individual uses, medical insurance, frequency of visits by the Community Health Agent (CHA) and frequency of use of the health center in the year prior to the interview).

To assess the satisfaction of the octogenarians, the Satisfaction with Primary Health Care Questionnaire, validated in Brazil, was applied ${ }^{15}$. This is composed of 33 items divided into five dimensions (Facilities of Unit; Reception at Unit by Community Health Agent; Treatment by nurse; Medical Treatment; Perceptions and General Needs). The responses to the items were organized on a Likert type scale based on agreement, divided into seven points, namely: 1-totally disagree; 2-strongly disagree; 3-disagree a little; 4-neither agree nor disagree; 5 -I agree a little; 6-strongly agree and 7-totally agree.

Descriptive analysis of the variables was carried out. The values of the Likert scale were treated numerically (there was no reverse question scoring as the Likert gradation relates the highest value to the best scenario).

Regarding ethical aspects, the study complied with Resolution 466/2012 of the National Health Council, and the research was approved by the Research Ethics Committee of the Universidade Federal do Triângulo Mineiro, in 2017, under approval number 2,041,624. The objectives of the research were explained and any doubts were resolved. The interviews were carried out after the participant signed an Informed Consent Form.

\section{RESULTS}

Thirty octogenarians participated in the study. The mean age was 83.7 years, the minimum age was 80 and the maximum age was 91 . None of the older participants showed signs of cognitive decline. 
Regarding the sociodemographic profile of the octogenarians, $56.7 \%$ were female, most were widowed $(53.3 \%)$, white $(43.3 \%)$, Catholic $(66.6 \%)$, with between one to four full years of schooling (53.5\%), retired and without a professional occupation $(93.3 \%)$, with an individual income of one minimum wage (73.3\%) and a family income of one to three minimum wages $(60.0 \%)$, with a household arrangement mainly composed of new forms of arrangements (56.6\%), representing older adults who lived only with their grandchildren and those who lived with other people with whom they did not have family ties.

Regarding the health conditions of the elderly, most did not use tobacco or alcohol (70.0\% for both) and did not participate in physical activities (66.7\%). Among the elderly who practiced physical activity $(33.3 \%)$, walking $(56.3 \%)$, water aerobics $(18.8 \%)$ and guided aerobic activities (12.5\%) were preferred.

As for access to health services, almost all respondents reported using the public health service $(93.3 \%)$ and not having private health insurance $(56.7 \%)$. More than half received at least one visit per month from the CHA (53.3\%) and attended the health service to which they were registered at least once a month (53.3\%) (Table 1).

In the analysis of the items that make up the Primary Care Satisfaction assessment instrument, based on the average values shown in Table 2 , the most positively assessed items were: Community agents are attentive (Average $=6.0 ; \pm 1.5$ ); Community agents are interested in the user's problems and in resolving such problems (Average $=5.9 ; \pm 1.6$ ); Community Health Agents clearly explain what user should do (Average $=5.9$; \pm 1.6 ). In addition to Nurse is usually available to treat the user (Average $=5.9 ; \pm 1.1$ ), Nurses are competent in the treatment they provide (Average $=5.9 ; \pm 1.4$ ) and Nurses are attentive (Average $=5.9 ; \pm 1.3$ ).

The items with the lowest scores were: user normally does not have to wait long for treatment - Nurse (Average $=4.6 ; \pm 1.6$ ); user normally does not have to wait long for treatment - Doctor (Average $=4.9 ; \pm 1.6$ ); the clinic has adequate facilities for people with disabilities (Average $=4.9 ; \pm 1.4$ ) and this health unit is very close to a perfect health unit (Average $=4.9 ; \pm 1.8$ ). 
Table 1. Distribution of clinical aspects and access to health services of octogenarians registered in the Family Health Service (N=30). Uberaba, Minas Gerais, 2017.

\begin{tabular}{|c|c|}
\hline Clinical aspects and access to health services & $\mathrm{n}(\%)$ \\
\hline \multicolumn{2}{|l|}{ Smoker } \\
\hline Yes & $1(3.3)$ \\
\hline No & $21(70.0)$ \\
\hline Ex-smoker & $8(26.7)$ \\
\hline \multicolumn{2}{|l|}{ Alcohol intake } \\
\hline Yes & $6(20.0)$ \\
\hline No & $21(70.0)$ \\
\hline Ex-alcoholic & $3(10.0)$ \\
\hline \multicolumn{2}{|l|}{ Physical activity } \\
\hline Yes & $10(33.3)$ \\
\hline No & $20(66.7)$ \\
\hline \multicolumn{2}{|l|}{ Type of physical activity* } \\
\hline Walking & $9(56.3)$ \\
\hline Water aerobics & $3(18.8)$ \\
\hline Guided aerobic activities (health service) & $2(12.5)$ \\
\hline Other & $2(12.5)$ \\
\hline \multicolumn{2}{|l|}{ Morbidities* } \\
\hline Diabetes Mellitus type II & $14(14.9)$ \\
\hline Systemic Arterial Hypertension & $24(25.5)$ \\
\hline Osteoporosis & $12(12.8)$ \\
\hline Varicose Veins & $15(16.0)$ \\
\hline Heart problems & $12(12.8)$ \\
\hline Obesity & $1(1.1)$ \\
\hline Parkinson's Disease & $2(2.1)$ \\
\hline Alzheimer's Disease & $1(1.1)$ \\
\hline Urinary incontinence & $6(6.4)$ \\
\hline Fecal incontinence & $3(3.2)$ \\
\hline Constipation & $4(4.3)$ \\
\hline \multicolumn{2}{|l|}{ Type of health service used } \\
\hline Public & $21(70.0)$ \\
\hline Private & $2(6.7)$ \\
\hline Both & $7(23.2)$ \\
\hline \multicolumn{2}{|l|}{ Possesses medical insurance } \\
\hline Yes & $13(43.3)$ \\
\hline No & $17(56.7)$ \\
\hline \multicolumn{2}{|l|}{ Frequency of Community Health Agent visits } \\
\hline Less than once a month & $16(53.3)$ \\
\hline Once per month & $14(46.7)$ \\
\hline \multicolumn{2}{|l|}{ Frequency of use of health services (FHS) } \\
\hline Less than once a month & $14(46.7)$ \\
\hline Once per month & $16(53.3)$ \\
\hline
\end{tabular}

*Each participant could choose more than one alternative. 
Table 2. Scores for satisfaction with Primary Health Care for octogenarians according to satisfaction groups ( $\mathrm{N}=30)$. Uberaba, Minas Gerais, 2017.

\begin{tabular}{|c|c|c|}
\hline $\begin{array}{l}\text { Items and domains of the Satisfaction with } \\
\text { Primary Health Care instrument }\end{array}$ & Average $( \pm$ sd) & Median $(95 \% \mathrm{CI})$ \\
\hline \multicolumn{3}{|l|}{ Facilities of unit } \\
\hline The facilities look good & $5.3(1.5)$ & $6.0(4.8 ; 5.9)$ \\
\hline The facilities have a pleasant temperature & $5.2(1.6)$ & $5.0(4.6 ; 5.8)$ \\
\hline The facilities are comfortable & $5.5(1.5)$ & $6.0(4.9 ; 6.1)$ \\
\hline The facilities are clean & $5.5(1.3)$ & $6.0(5.0 ; 6.0)$ \\
\hline Bathrooms are hygienic & $5.5(1.3)$ & $6.0(5.0 ; 6.0)$ \\
\hline The consulting rooms have enough space & $5.5(1.2)$ & $6.0(5.0 ; 5.9)$ \\
\hline The clinic has facilities suitable for the disabled & $4.9(1.4)$ & $5.0(4.4 ; 5.5)$ \\
\hline Services are well signposted & $5.4(1.3)$ & $6.0(4.9 ; 5.9)$ \\
\hline Opening hours are tailored to the user's needs & $5.3(1.8)$ & $6.0(4.6 ; 6.0)$ \\
\hline In this clinic there is information about health care & $5.6(1.5)$ & $6.0(5.1 ; 6.2)$ \\
\hline \multicolumn{3}{|l|}{ Reception at the unit is carried out by the Community Health Agent (CHA) } \\
\hline The CHAs are attentive & $6.0(1.5)$ & $7.0(5.4 ; 6.6)$ \\
\hline $\mathrm{CHAs}$ are interested in the user's problems and resolving them & $5.9(1.6)$ & $7.0(5.3 ; 6.5)$ \\
\hline CHAs clearly explain what the user should do & $5.8(1.6)$ & $6.0(5.2 ; 6.4)$ \\
\hline User does not normally have to wait long for treatment & $5.2(1.5)$ & $5.0(4.6 ; 5.7)$ \\
\hline \multicolumn{3}{|l|}{ Nursing Treatment } \\
\hline Nurses are attentive & $5.8(1.3)$ & $6.0(5.4 ; 6.3)$ \\
\hline Nurses are interested in the user's problems and resolving them & $5.7(1.2)$ & $6.0(5.2 ; 6.2)$ \\
\hline Nurses do everything they can to solve the user's problem & $5.7(1.3)$ & $6.0(5.2 ; 6.2)$ \\
\hline Nurses clearly explain the treatment they will perform & $5.6(1.7)$ & $6.0(4.9 ; 6.2)$ \\
\hline Nurses are competent in the treatments they perform & $5.8(1.4)$ & $6.0(5.3 ; 6.3)$ \\
\hline Usually the Nurse is available to treat the user & $5.9(1.1)$ & $6.0(5.4 ; 6.2)$ \\
\hline Nurses are respectful of appointment times & $5.7(1.3)$ & $6.0(5.2 ; 6.2)$ \\
\hline User does not normally have to wait long for treatment & $4.6(1.6)$ & $5.0(4.0 ; 5.2)$ \\
\hline \multicolumn{3}{|l|}{ Treatment by Doctor } \\
\hline Doctors are attentive & $5.6(1.5)$ & $6.0(5.0 ; 6.1)$ \\
\hline CHAs are interested in the user's problems and resolving them & $5.6(1.5)$ & $6.0(5.0 ; 6.2)$ \\
\hline Doctors clearly explain the treatment they will perform & $5.6(1.3)$ & $6.0(5.1 ; 6.1)$ \\
\hline Doctors do everything they can to solve the user's problem & $5.6(1.4)$ & $6.0(5.0 ; 6.1)$ \\
\hline Doctors are competent in the treatments they perform & $5.6(1.7)$ & $6.0(4.9 ; 6.2)$ \\
\hline Doctors are respectful of appointment times & $5.2(1.7)$ & $6.0(4.5 ; 5.8)$ \\
\hline User does not normally have to wait long for treatment & $4.9(1.6)$ & $5.0(4.3 ; 5.5)$ \\
\hline \multicolumn{3}{|l|}{ Overall } \\
\hline In general, the user is satisfied with the services of this Health Unit (HU) & $5.2(1.5)$ & $5.5(4.7 ; 5.8)$ \\
\hline This HU meets the user's needs & $5.3(1.7)$ & $6.0(4.7 ; 5.9)$ \\
\hline This HU meets the user's expectations & $5.1(1.6)$ & $5.5(4.5 ; 5.7)$ \\
\hline This Health Unit is very close to a perfect Health Unit & $4.9(1.8)$ & $5.5(4.2 ; 5.5)$ \\
\hline
\end{tabular}

Sd: Standard deviation; 95\% CI - 95\% confidence interval. 


\section{DISCUSSION}

The results of the present study are consistent with other studies with octogenarians, in terms of sociodemographic profile: there was a higher frequency of women, aged between 80 and 84 years, who were widows, had low levels of education, an individual income below the minimum wage, were retirees and had a large number of morbidities ${ }^{2,16,17}$.

The predominance of octogenarian women corroborates the fact that men have higher mortality rates and women higher survival rates ${ }^{16}$. The low levels of education may be related to cultural aspects. In addition to access to schools, this situation may be the result of cultural and generational factors, which results from the non-stimulus for these individuals to attend school, as well as labor activities being related to low schooling, which ends up affecting financial conditions ${ }^{17,18}$.

The Brazilian National Health Service (SUS) is important to the population studied, 93.3\% of which reported using it. As the population of the study is a group of octogenarians with specific characteristics related to the aging process, recognizing the importance of this health system, as a social protection policy, becomes crucial if it is to continue to be strengthened. The results confirm the constant use of health services by octogenarians, as all the respondents used the services of the FHS (Family Health Strategy) at least once a month ${ }^{4,6,11,19}$.

Despite their multimorbidities, one third of the group interviewed were regular practitioners of physical activity. Walking was the most frequent activity, coinciding with the findings of the healthy aging profile of elderly Brazilian octogenarians ${ }^{2}$.

However, octogenarians evaluated their satisfaction with primary healthcare services as favorable (all $\mathrm{Md} \geq 5$ ), representing satisfaction. The information obtained shows that satisfaction with the work of the Nursing team and CHAs is greater. Literature shows that such a situation may be related to the care that these professionals provide to longlived older adults, listening to their problems and giving them clear guidance on how to manage the health service ${ }^{6,8,11,19}$.
This fact can be related to the specificity of the work process in the FHS, which puts these workers, nursing staff and CHAs in constant contact with the population and on the front lines of $\operatorname{car}^{20}$. It is these workers who usually carry out the screening of care needs and intake, and who make the most use of home visits in their work. This explains the importance of understanding the satisfaction expressed by octogenarians in relation to these workers $^{21,22}$.

Satisfaction with services can result from interpersonal relationships between professionals and patients, from the users' own social representations in relation to the health-disease process, as well as aspects related to the infrastructure of services. When attempting to understand the satisfaction of older adults with the FHS in the city of Fortaleza (Ceará), it was found that a large part of the participants $(82.1 \%)$ were satisfied with aspects related to the care provided by these professionals, with good service and a bond with the professionals of the unit ${ }^{2}$.

A study that evaluated the degree of satisfaction of older adults with CHAs identified that the greatest satisfaction with these professionals was related to the domain of trust ${ }^{23}$, which corroborates the findings of the present study in relation to the greater satisfaction of the octogenarians with these healthcare workers, as a result of the care undertaken in their work.

It is essential that the professional practices of those inserted in the PHC is humanized, with a welcoming manner that creates bonds ${ }^{4,9,17}$. A good relationship between users and health professionals is associated with the likelihood of generating greater satisfaction with the service, including the care of professionals who work in the reception of the units, a flexible waiting system with short waits for consultations and good relationships with professionals ${ }^{24}$. The interactions between professional and patient can contribute to long-term affective approximation, which can be a facilitator with regard to the users' perception of the effectiveness of the FHS.

The point of greatest dissatisfaction revealed by the group of octogenarians was the time spent waiting for care, represented by the time of arrival at the unit until the appointment with the scheduled 
health professional (Nursing Md = 4.6 Q25-Q75 = 4-6; Doctors $\mathrm{Md}=4.9 \mathrm{Q} 25-\mathrm{Q} 75=4-6)$. The delay in being seen, whether for a spontaneous health service or a previously scheduled appointment, has been identified as a constraining factor with other primary care teams, as noted in João Pessoa (Paraíba) ${ }^{25}$.

It is recommended by the national primary care policy that the work process of the FHS teams be carried out in accordance with the population's health needs, based on humanized intake, active listening and responsibility for resolving spontaneous needs and the priority provision of emergency care. Thus, it is expected that in addition to the activities previously scheduled by the services, PHC will be able to meet the spontaneous demands of its users in order to guarantee its role as the organizer of the actions and services that are part of the HCN (Healthcare Network, or RAS) ${ }^{26}$. Evidence ${ }^{26-28}$ has shown that the lengthy wait for consultations and the dissatisfaction with how reception for spontaneous needs for PHC services is handled are aspects of fragility and dissatisfaction with the service, which may lead users to seek care at other $\mathrm{HCN}$ points.

Another weak point is related to the unit's facilities and its suitability for the disabled. In Recife (Pernambuco), a similar reality was identified, with older adults in this location demonstrating reduced satisfaction with the physical and infrastructure conditions of the units. Poor accessibility, limitations in comfort and hygiene conditions are the most critical aspects pointed out by the group of older adults in Recife ${ }^{29}$.

When assessing the expectations and experiences of older users of PHC services in the province of KwaZulu-Natal, in South Africa, aspects of dissatisfaction were identified as the delay in waiting for appointments, a model of care based on diseases, the absence of a bond with health professionals and the need to create priority access for this group ${ }^{30}$.

One of the benefits of this study is for health professionals, especially those inserted in the PHC context, who must take into account the perspective of users when planning their actions. The evaluation of the quality of health services, from the perspective of users, is capable of instituting changes and overcoming the hegemonic biomedical model, in addition to directing actions to make sense of the unique realities of life of long-lived older users.

A study undertaken with older users of PHC services in João Pessoa (Paraíba) identified as aspects of dissatisfaction of older adults with PHC services, the speed and completion of scheduling appointments, lack of comfort in the facilities of the unit, the commitment of the healthcare team to solving their problems and the team's knowledge about their health problems and needs, findings that corroborate those of this study ${ }^{31}$.

Although PHC services should consider health actions for the elderly population in a comprehensive manner, there is a greater concentration of activities related to chronic non-communicable diseases. When assessing the performance of comprehensive care for the elderly in PHC services in health regions in the center-west region of São Paulo, a predominance of actions based on the hegemonic biomedical model was identified and health promotion and prevention actions are implemented in a scarce and inefficient manner. When such actions are undertaken, they are aimed at controlling systemic arterial hypertension and diabetes mellitus ${ }^{11}$.

In this context, there is a disconnect between what the service provided to the older population as recommended by the National Policy for Older Adults and the actions implemented in practice, since it is expected that the service provided to this group goes beyond the process of the treatment of pathologies, and towards the development of healthy aging with quality of life $\mathrm{e}^{2,5,9,11}$.

Another contribution is related to the guidelines for local health management in the city where the study is being carried out, so that organization strategies are continuously improved in order to generate more purposeful responses from health services to the long-lived population ${ }^{29}$. Furthermore the FHS teams themselves, through the findings of this study, can realign their work strategies to provide a better intake process and resolve the demands of the age group of long-lived older adults. 
Studies involving octogenarians are scarce - given the difficulties in accessing this population caused by the aging process itself. This makes the findings of the present study relevant in contributing to the understanding of the phenomenon studied.

Furthermore, although the results of the analyzes undertaken are descriptive, without the establishment of causal relationships, they can contribute to future studies, in particular by supporting sample calculations in population-based studies with octogenarians. The fact that non-probabilistic sampling was used, as well as the possibility of memory bias, must also be highlighted.

It is expected that future research will recognize whether there is a common pattern between satisfaction with PHC services among long-lived older adults in population-based studies, in addition to establishing relationships between sociodemographic and clinical aspects and service satisfaction. There should also be an analysis of what actions have been carried out by the health teams and the initiatives offered to long-lived older adults, that address their satisfaction with health services.

\section{CONCLUSION}

In general, the octogenarians favorably evaluated the primary care services with which they had contact, with the aspects of dissatisfaction related to the delay in receiving care and the infrastructure of the unit. The aspects of satisfaction were related to the fact that the team of Community Health Agents are attentive, explain what should be done, are interested in their problems and are available.

The results contribute in a purposeful way to the management, improvement and training of health services, as well as supporting the working process, reaffirming the importance of the participation of octogenarians in the evaluation of health services.

Edited by: Ana Carolina Lima Cavaletti

\section{REFERENCES}

1. Instituto Brasileiro de Geografia e Estatística. Projeção da população do Brasil por sexo e idade 2000-2060 [Internet]. Rio de Janeiro: IBGE; 2013 [acesso em 05 jul. 2019].Disponível em: ftp://ftp. ibge.gov.br/Projecao_da_Populacao/Projecao_da_ Populacao_2013/nota_metodologica_2013.pdf

2. Campos ACV, Ferreira EF, Vargas AMD, Gonçalves LHT. Perfil do envelhecimento saudável de idosos brasileiros octogenários. Rev Latinoam Enferm [Internet]. 2016 [acesso em 10 jul. 2019];24:e2724 [11]. Disponível em: http://www. scielo.br/scielo.php?script $=$ sci_arttext\&pid $=$ S0104$11692016000100398 \& \operatorname{lng}=$ pt\&nrm=iso\&tlng $=$ pt

3. Fernandes DS, Gonçalves LHT, Ferreira AMR, Santos MIPO. Avaliação da capacidade funcional de idosos longevos amazônidas. Rev Bras Enferm [Internet]. 2019 [acesso em 17 abr 2020];72(Suppl 2):55-61. Disponível em: http://www.scielo. br/scielo.php?script $=$ sci_arttext\&pid $=$ S003471672019000800049\&lng=pt\&tlng=pt

4. Rêgo AS, Rissardo LK, Scolari GAS, Sanches RCN, Carreira L, Radovanovic CAT. Fatores associados ao atendimento a idosos por condições sensíveis à Atenção Primária à Saúde. Rev Bras Geriatr Gerontol [Internet]. 2017 [aceso em 10 jul. 2019];20(6):778-89. Disponível em: http://www. scielo.br/scielo.php?script $=$ sci_arttext\&pid=S180998232017000600773\&lng=en\&tlng=pt

5. Brasil. Ministério da Saúde, Departamento de Atenção Básica, Secretaria de Atenção à Saúde. Envelhecimento e saúde da pessoa idosa. Brasília, DF: MS; 2006. (Cadernos de atenção básica, no 19 )

6. Sória GS, Nunes BP, Bavaresco CS, Vieira LS, Facchini LA. Acesso e utilização dos serviços de saúde bucal por idosos de Pelotas, Rio Grande do Sul, Brasil. Cad Saúde Pública [Internet]. 2019 [acesso em 17 abr. 2020];35(4):e00191718 [12 p.]. Disponível em: http://www.scielo.br/scielo.php?script=sci_ arttext\&pid=S0102-311X2019000405011 
7. Veras RP, Oliveira M. Envelhecer no Brasil: a construção de um modelo de cuidado. Ciênc Saúde Colet [Internet]. 2018 [aceso em 10 jul. 2019];23(6):1929-38. Disponível em: http://www.scielo.br/scielo.php?script=sci_ arttext\&pid=S1413-81232018000601929

8. Lima JG, Giovanella L, Fausto MCR, Bousquat A, Silva EV. Atributos essenciais da Atenção Primária à Saúde: resultados nacionais do PMAQAB. Saúde Debate [Internet]. 2018 [acesso em 29 jun. 2019];42(esp.):52-6. Disponível em: http://www.scielo.br/scielo.php?script=sci_ arttext\&pid=S0103-11042018000500052

9. Camargo FC, Garcia LAA, Walsh IAP, Emílio MM, Coelho VHM, Pereira GA. Formação para o trabalho na estratégia saúde da família: experiência da residência multiprofissional em saúde. Rev Enferm Atenção Saúde [Internet]. 2018 [acesso em 11 set. 2019];7(1):190-9. Disponível em: http://seer.uftm.edu. $\mathrm{br} /$ revistaeletronica/index.php/enfer/article/view/2127

10. Navathe AS, Emanuel EJ, Bond A, Linn K, Caldarella K, Troxel A. Association between the implementation of a population-based Primary Care Payment System and achievement on quality measures in Hawaii. JAMA. 2019;322(1):57-68.

11. Placideli N, Castanheira ERL, Dias A, Silva PA, Carrapato JLF, Sanine PR, et al. Avaliação da atenção integral ao idoso em serviços de atenção primária. Rev Saúde Pública [Internet]. 2020 [acesso em 17 abr. 2020];54:1-13. Disponível em: http://www.rsp.fsp.usp. br/artigo/avaliacao-da-atencao-integral-ao-idoso-emservicos-de-atencao-primaria/

12. Brasil. Ministério da Saúde. DATASUS. Informações de Saúde, Informações demográficas e socioeconômicas. Brasília,DF: MS; 2019.

13. Nardelli GG, Gaudenci EM, Silveira RE, Garcia LAA, Malaquias BSS, Santos ASS. Knowledge about HIV/AIDS in older adults using the services of Family Health Strategy. Rev Soc Bras Med Trop [Internet]. 2019 [acesso em 11 set. 2019];52:e20180355 [5 p.]. Disponível em: https://rsbmt.org. br/2019/07/11/knowledge-about-hiv-aids-in-olderadults-using-the-services-of-family-health-strategy/

14. Brucki SMD, Nitrini R, Caramelli P, Bertolucci PHF, Okamoto IH. Suggestions for utilization of the mini-mental state examination in Brazil. Arq Neuropsiquiatr. 2003;61:777-81.

15. Paz EPA, Parreira PMSD, Lobo AJS, Palasson RR, Farias SNP. Adaptação transcultural do questionário de satisfação com os cuidados primários de saúde. Acta Paul Enferm [Internet]. 2014 [acesso em 13 mar. 2016];27(5):419-26. Disponível em: http://www. scielo.br/scielo.php?script=sci_arttext\&pid=S0103$21002014000500006 \& \operatorname{lng}=\mathrm{en} \& \mathrm{nrm}=\mathrm{iso} \& \ln \mathrm{l}=\mathrm{pt}$
16. Tavares DMS, Ribeiro AG, Ferreira PCS, Martins NPF, Pegorari MS. Idosos octogenários nos contextos urbano e rural: comparação socioeconômica, morbidades e qualidade de vida. Rev Enferm UERJ [Internet]. 2015 [acesso em 29 ago. 2019];23(2):156-63. Disponível em: https://www.e-publicacoes.uerj.br/ index.php/enfermagemuerj/article/view/5961

17. Augusto DK, Lima-Costa MF, Macinko J, Peixoto SV. Fatores associados à avaliação da qualidade da atenção primária à saúde por idosos residentes na Região Metropolitana de Belo Horizonte, Minas Gerais, 2010. Epidemiol Serv Saúde [Internet]. 2019 [acesso em 24 jul. 2019];28(1):e2018128 [11 p.]. Disponível em: http://www.scielo.br/scielo.php?script $=$ sci_ arttext\&pid=S2237-96222019000100316

18. Tavares DMS, Ferreira PCS, Dias FA, Oliveira PB. Caracterização e distribuição espacial de homens octogenários. Rev Enferm UERJ [Internet]. 2014 [acesso em 12 set. 2019]; 22(4):558-64. Disponível em: https://www.e-publicacoes.uerj.br/index.php/ enfermagemuerj/article/view/15425

19. Pilger C, Menon UM, Mathias TAF. Utilização de serviços de saúde por idosos vivendo na comunidade. Rev Esc Enferm USP [Internet]. 2013 [acesso em 11 set. 2019];47(1):213-20. Disponível em: https://www. scielo.br/scielo.php?script $=$ sci_arttext\&pid $=\mathrm{S} 0080$ 62342013000100027\&lng=pt\&tlng=pt

20. Ferreira SRS, Périco LAD, Dias VRFG. A complexidade do trabalho do enfermeiro na Atenção Primária à Saúde. Rev Bras Enferm [Internet]. 2018 [acesso em 22 ago. 2019];71(supl1):752-7. Disponível em: http://www. scielo.br/scielo.php?script $=$ sci_arttext\&pid $=$ S0034$71672018000700704 \& \operatorname{lng}=$ en\&tlng $=$ pt

21. Galavote HS, Zandonade E, Garcia ACP, Freitas PSS, Seidl H, Contarato PC. O trabalho do enfermeiro na atenção primária à saúde. Esc Anna Nery [Internet]. 2016 [acesso 13 mar. 2019];20(1):90-8. Disponível em: http://www.scielo. $\mathrm{br} /$ scielo.php?script $=$ sci_abstract\&pid=S1414$81452016000100090 \& \operatorname{lng}=$ en\&tlng=pt

22. Kahl C, Meirelles BHS, Lanzoni GMM, Koerich C, Cunha KS. Actions and interactions in clinical nursing practice in Primary Health Care. Rev Esc Enferm USP [Internet]. 2018 [acesso em 12 set. 2019];52:e03327 [7 p.]. Disponível em: http://www. scielo.br/scielo.php?script $=$ sci_abstract\&pid $=\mathrm{S} 0080$ 62342018000100415\&lng=en\&tlng=en

23. Bordin D, Fadel CB, Moimaz SAS, Garbin CAS, Saliba NA. Estudo comparativo da satisfação de usuários e profissionais da saúde com o serviço público odontológico. Ciênc Saúde Colet [Internet]. 2017 [acesso em 18 abr. 2020];22(1):151-60. Disponível em: http://www.scielo.br/scielo.php?script $=$ sci_ arttext\&pid=S1413-81232017000100151 
24. Arruda CAM, Bosi MLM. User's satisfaction of primary health care: a qualitative study in the Northeast of Brazil. Interface (Botucatu) [online]. 2017 [acesso em 29 dez. 2017];21(61):32132. Disponível em: https://www.scielo.br/ scielo.php?script $=$ sci_arttext\&pid=S1414$32832017000200321 \& \operatorname{lng}=\mathrm{pt \& t} \operatorname{lng}=\mathrm{pt}$

25. Santiago RF, Mendes ACG, Miranda GMD, Duarte PO, Furtado BMASM, Souza WV. Qualidade do atendimento nas Unidades de Saúde da Família no município de Recife: a percepção do usuários. Ciênc Saúde Colet [Internet]. 2013 [acesso em 29 dez. 2018];18(1):35-44. Disponível em: https://www. scielosp.org/article/csc/2013.v18n1/35-44/

26. Dias OV, Araújo FF, Oliveira RM, Chagas RB, Costa SM. Acesso às consultas médicas nos serviços públicos de saúde. Rev Bras Med Fam Comunidade [Internet]. 2016 [acesso em 01 maio 2020];11(38):113. Disponível em: https://rbmfc.emnuvens.com.br/ $\mathrm{rbmfc/article/view/1185}$

27. Souza ROA, Machado CV, Noronha MF. Desafios da gestão municipal da atenção básica em saúde no Brasil: um estudo de caso. Rev APS [Internet]. 2015 [acesso em 01 maio 2020];18(2):166-79. Disponível em: https:// periodicos.ufjf.br/index.php/aps/article/view/15584
28. Gomide MFS, Pinto IC, Bulgarelli AF, Santos ALP, Gallardo MPS. User satisfaction with primary health care: an analysis of access and care. Interface (Botucatu) [Internet] 2018 [acesso em 01 maio 2020];22(65):387-98. Disponível em: https://www.scielo.br/scielo.php?script=sci_ arttext\&pid=S1414-32832018000200387

29. Ravioli AF, Soárez PC, Scheffer MC. Modalidades de gestão de serviços no Sistema Único de Saúde: revisão narrativa da produção científica da Saúde Coletiva no Brasil (2005-2016). Cad Saúde Pública [Internet]. 2018 [acesso em 23 jun. 2019];34(3):e00114217 [16 p.]. Disponível em: http://www.scielo.br/ scielo.php?script=sci_arttext\&pid=S0102311X2018000402001

30. Naidoo K, Wyk J. What the elderly experience and expect from primary care services in KwaZuluNatal, South Africa. Afr J Prim Health Care Fam Med (Online) [Internet]. 2019 [acesso em 18 abr. 2020];11(1):1-10. Disponível em: https://phcfm.org/ index.php/phcfm/article/view/2100/3413

31. Andrade LAF, Salazar PEL, Leopoldino KDM, Montenegro CB. Avaliação da qualidade da atenção primária à saúde segundo o nível de satisfação dos idosos. Rev Gaúcha Enferm [Internet]. 2019 [acesso em 18 ab.r 2020];40:e20180389 [10 p.]. Disponível em: http://www.scielo.br/scielo.php?script=sci_ arttext\&pid=S1983-14472019000100428 